\title{
Evaluation of Antiinflammatory Activity of Marine Omega-3 in Rats
}

\author{
Ana Khusnul Faizah*, Angelica Kresnamurti \\ Department of Clinical Pharmacy, Pharmacy, Hang Tuah University, Surabaya, Indonesia
}

\begin{abstract}
Marine omega-3 from fish contains high EPA dan DHA which may have an analgesic and anti-inflammatory effects. The objective of study was to analyze the antiinflammatory effect of marine omega- 3 in rats. The method of this study was pre-post control experimental. The acute anti-inflammatory effect of marine omega-3 were investigated through carrageenan induced paw edema in rats. Thirty minutes before the procedure, the experimental groups were treated with fish oil 40 and $60 \mathrm{mg} / \mathrm{kg} \mathrm{BW}$; sodium diclofenac $(5 \mathrm{mg} / \mathrm{kg} \mathrm{BW})$ as positive control groups and span $80(1.4 \%)$-tween 80 (3.6\%) as negative control groups. The degree of paw edema was measured by caliper. The marine omega-3 showed anti-inflammatory effect in a dose-dependent manner. The results of $60 \mathrm{mg} / \mathrm{kg}$ BW of marine omega-3 was significantly different compared with the negative $(\mathrm{P}=0.00)$. Overall, the marine omega-3 has acute anti-inflammatory activity in rats.
\end{abstract}

Keyword: Antiinflammatory, Fish Oil, Marine Omega-3, Sodium Diclofenac

\begin{abstract}
Abstrak. Omega-3 berasal dari minyak ikan mengandung EPA dan DHA dalam jumlah besar. EPA dan DHA memiliki efek analgesik dsan antiinflamasi. Tujuan penelitian I I untuk menganalisis efek antiinflamasi omega-3 dari minyak ikan pada tikus. Metode yang digunakan adalah penelitian eksperimental dengan pengukuran di awal dan akhir pada kelompok control dan uji. Efek antiiflamasi akut dilihat melalui edema yang diinduksi oleh karagenin. Tiga puluh menit sebelum pemberian karagenin, kelompok uji diberi minyak ikan dosis 40 dan $60 \mathrm{mg} / \mathrm{Kg} \mathrm{BB}$, natrium diklofenak sebagai kontrol positif dan span 80 serta tween 80 sebagai kontrol negatif. Pengukuran edema dilakukan menggunkan jangka sorong. Hasil pada kelompok uji dosis $60 \mathrm{mg} / \mathrm{kg}$ BB menunjukkan adanya perbedaan signifikan dengan kelompok kontrol negatif. Dari hasil penelitian, dapat disimpulkan bahwa omega-3 dari minyak ikan dapat memberikan efek antiinflamasi pada tikus
\end{abstract}

Kata Kunci: Antiinflamasi, Omega-3 Marine, Minyak Ikan, Natrium Diklofenak

Received 27 October 2019 | Revised 12 December 2019 | Accepted 14 December 2019

\section{Introduction}

Antiinflammatory is a medicine to reduce the inflammatory process. Non-Steroid Antiinflammatory Drug (NSAID) is an antiinflmaatory that acts on the arachidonic acid pathway by inhibiting the enzymes cyclooxygenation-1 (COX-1) and cyclooxygenase-2 (COX2). Sodium diclofenac, mefenamic acid, ibuprofen, ketorolac and piroxicam are NSAID [1].

*Corresponding author at: Department of Clinical Pharmacy, Pharmacy, Hang Tuah University, Surabaya, Indonesia E-mail address: ana.faizah@hangtuah.ac.id 
Some anti-inflammatory drugs in Indonesia can be obtained without using a doctor's prescription. We can get ibuprofen or mefenamic acid as the over the counter (OTC) medicine. Inappropriate use of NSAIDs can cause undesired effects including gastrointestinal disorders and decreased kidney function. The prevalence of gastric ulcer in patients using low-dose aspirin is $10-40 \%$ [2]. Peptic ulcers that occur during NSAID use also occur in $14 \%$ of patients and the drugs that most often cause these side effects are sodium diclofenac and aspirin [3].

Indonesia is known as a maritime country that has marine potential which ranks second in the world after China [4]. One of the marine fish products is fish oil which contains $25 \%$ saturated fatty acids and $75 \%$ unsaturated fatty acids. Omega-3 is one of the unsaturated fatty acids that is essential for the body and is needed especially for people with high cholesterol. EPA and DHA are the most dominant types of omega-3 in fish oil [5]. The synthetic analgesic has several adverse drug reactions such as gastric bleeding and Steven Johnson's Syndrome. We want to have marine analgesic that have lower adverse drug reactions. This study aims to determine the anti-inflammatory activity of fish oil in white male wistar rats (Rattus norvegicus L.).

\section{Materials and Method}

This research was a laboratory experimental study with pre and post-test control group using experimental animals wistar rats (Rattus norvegicus L.). The study was conducted at the Laboratory of Pharmacy at the Medical Faculty of Hang Tuah University and approved by the Medical Faculty of UHT by number of 03.F.2/HC/EC/KEPUHT/2018. We used two types of measurement namely plethysmometer and calipers to measure the thickness of edema in the rat's hind paw.

\subsection{Rats}

Rats were prepared by an adaptation process in a cage for a week. During the process, rats eat and drink, then fasted 12-18 hours before treatment and still given a drink. The rats were weighed and grouped into 4 groups of 6 rats. Rats were classified into negative control group (span $80(1.4 \%)$ and tween 80 (3.6\%) orally); positive control group (sodium diclofenac $5 \mathrm{mg} /$ $\mathrm{kg} \mathrm{BW}$ orally) and fish oil (40 and $60 \mathrm{mg} / \mathrm{kg} \mathrm{BW}$ orally).

\subsection{Carageenan-induced paw edema test}

Before being given treatment, measurements of the volume of rat foot edema were carried out and recorded as preliminary data. Furthermore, the rats were treated according to their groups. In the $30^{\text {th }}$ minute, $1 \%$ caragenin was injected into the submarine's right back foot of $0.1 \mathrm{ml}$. At the $60^{\text {th }}, 90^{\text {th }}, 120^{\text {th }}$ and $180^{\text {th }}$ minutes after $1 \%$ caragenin injection was measured the volume of edema using caliper according to each group. 


\subsection{Statistycal Analysis}

Subplantar thick data was processed with the SPSS 22.0 program using one way ANOVA analysis and continued with Post Hoc Test LSD. P<0.05 was consideres statistically significant.

\section{Result and Discussion}

The average value of the paw edema for each group by the caliper is shown in Table 1. The induction agent chosen in this study is caragenin because it has special benefits as an irritant used in the effectiveness of anti-inflammatory drugs and acute inflammatory-inducing compound in test animals without causing damage to the feet of inflamed test animals. Caragenin induces edema through three phases. The first phase is the release of histamine and serotonin which lasts up to 90 minutes. The second phase is the release of bradykinin which occurs 1.5 to 2.5 hours after induction. In the third phase, prostaglandin release occurs 3 hours after induction, then edema develops rapidly and persists at a maximum volume of about 5 hours after induction [6].

At the 120th to 180th minute observations there was an increase in edema volume in the control group (+). Provision of salmon oil with a dose of $60 \mathrm{mg} / \mathrm{kg} \mathrm{BW}$ is the highest potential dose in inhibiting edema. This can be interpreted that a dose of $60 \mathrm{mg} / \mathrm{kg}$ is the most effective dose when compared with a dose of $40 \mathrm{mg} / \mathrm{kg}$ in reducing edema.

Table 1. Anti-inflammatory activity of marine omega-3 by caliper

\begin{tabular}{lccccc}
\hline \multicolumn{1}{c}{ Group } & \multicolumn{5}{c}{ \% increase in paw volume } \\
\cline { 2 - 6 } & $\mathbf{0}$ & $\mathbf{6 0}$ & $\mathbf{9 0}$ & $\mathbf{1 2 0}$ & $\mathbf{1 8 0}$ \\
\hline Control negative & $0.57 \pm 0.00$ & $0.67 \pm 0.03$ & $0.56 \pm$ & $0.73 \pm$ & $0.75 \pm 0.05$ \\
& & & 0.34 & 0.05 & \\
Diclofenac sodium & $0.57 \pm 0.00$ & $0.55 \pm 0.01$ & $0.53 \pm$ & $0.53 \pm$ & $0.55 \pm 0.02$ \\
$(5 \mathrm{mg} / \mathrm{kg})$ & & & 0.02 & 0.03 & \\
Marine omega-3 & $0.57 \pm 0.00$ & $0.63 \pm 0.01$ & $0.61 \pm$ & $0.58 \pm$ & $0.61 \pm 0.01$ \\
$(40 \mathrm{mg} / \mathrm{kg})$ & & & 0.02 & 0.01 & \\
Marine omega-3 & $0.57 \pm 0.00$ & $0.61 \pm 0.04$ & $0.59 \pm$ & $0.58 \pm$ & $0.56 \pm 0.03$ \\
$(60 \mathrm{mg} / \mathrm{kg})$ & & & 0.04 & 0.04 & \\
\end{tabular}

The control group (+) was able to inhibit the greatest edema at the 120th minute observation of $49.97 \%$ compared by negative control group. The data obtained from calipers which shows that at the dose of fish oil $60 \mathrm{mg} / \mathrm{kg} \mathrm{BW}$ inhibits in the 120th minute with an average thickness plantar 0.58 with calipers method. 
Comparison of average edema in each group as well as comparison of the number of rat responses in the four treatment groups can be seen that the effect of salmon oil and diclofenac sodium have almost the same inflammatory inhibitory mechanism. In the control group giving salmon oil and diclofenac sodium seen the anti-inflammatory effect started working from the $60^{\text {th }}$ minutes. When entering the $120^{\text {th }}$ minutes, there was an increasing in edema volume in the soles of experimental animals. This proved that the caragenin used can cause synergistic edema by the mechanism of prostaglandin release at 3 hours after induction and edema is still developing and surviving at a maximum volume for about 5 hours after induction. This can be due to diclofenac sodium having a short half-life so that sodium diclofenac must be given in several doses per day and the drug is bound $97 \%$ to plasma protein and accumulated in synovial fluid after administration in experimental animals [7].

Omega-3 from fish oil showed a significant anti-inflammatory effect $(\mathrm{p}<0.05)$ compared to diclofenac sodium in male white wistar-induced caragenin strains by calipers. The results of this study are supported by research conducted by Azuma using fatty acids in rat apical periodontitis [8]. Another research of fish oil in acute inflammation rats were conducted by Arruda [9].

The mechanism of action of omega-3 as an anti-inflammatory can be related to the ability of omega-3 to inhibit the inflammatory response. EPA could act as substrate for COX dan LOX [10]. Masaro said that phospolipods that produced from EPA and DHA can stimulate resolution inflammation [11].

The results of this study are supported by several articles which conclude that omega-3 from fish oil has an anti-inflammatory effect. Further research is still needed to find out about ED50 fish oil as an atinflammatory, therapeutic benefits, side effects, toxic effects and the mechanism of action of omega-3 as an anti-inflammatory.

\section{Conclusion}

In summary, this study provided evidence that marine omega-3 has significant antiinflammatory effect when administered in $60 \mathrm{mg} / \mathrm{Kg} \mathrm{BW}$ in rats indue by carragenin.

\section{Acknowledgment}

The authors are grateful for Hang Tuah University.

\section{REFERENCES}

[1] BG. Katzung, B. Susan, Masters, and JT Anthony, Basic \& Clinical Pharmacology. New York: McGraw-Hill Medical, p. 3696, 2012. 
[2] K. Yamagata, K. Ishida, H. Takashi, S. Ohba, T. Shiigai, M. Narita, A. Koyama, Risk factor for chronic kidney disease in a community-based population : a 10 year follow-up study, Kidney Int. Vol. 71, no. 2. Pp 159-166. 2007.

[3] S. Hamid, J. Yakoob, W. Jafri, S. Abid, M. Islam, Frequency of NSAID induced peptic ulcer disease. J Pak Med Assoc. vol. 56 No. 5. pp. 218-222. 2006.

[4] KKP, 2016. Laporan Kinerja Kementrian Kelautan dan Perikanan, Kementerian Kelautan dan Perikanan Republik Indonesia, Jakarta. pp. 132-136. 2015.

[5] WS. Haris, "Review: Fish Oil Supplementation: Evidence For Health Benefits" Cleveland Clinic J. of Medicine, vol. 71, no. 3, pp 208-219. 2004.

[6] J. Necas, L. Bartosikova, "Carragenan: a review" Veterinarni Medicina, vol. 58, pp. 187205. 2013.

[7] JA. Aberg, CF Lacy, LL. Amstrong, MP. Goldman, and LL. Lance, Drug Information Handbook, 17 edition, Lexi-Comp for the American Pharmacists Association. 2009.

[8] MM. Azuma, G. JE, E. Ervolino, CBM. Cardoso, CB. Pipa, T. Kawai, LC. Conti, LTA. Cintra, Omega-3 fatty acids reduce inflammation in rat apical periodontitis, $J$ Endod. vol. 44 no. 4. pp 604-608. 2017.

[9] L. Arruda, FQ Ames, DR. Morais, R. Grespan, AP. Gil, MA. Silva, JV. Visentainer, RK. Cumn, CA. Bersani-Amado, " A single adminidtration of fish oil inhibits the acute inflammatory response in rats", Asian Pacific Journal of Tropical Medicine, vol. 10 no. 8 pp 765-772. 2017.

[10] P.C. Calder, "Marine omega-3 fatty acids and inflammatory processes: effects, mechanisms and clinical relevance" Biochim Biophys Acta. vol. 4. pp. 469-484. 2015.

[11] M. Massaro, E. Scoditti, M.A. Carluccio, R. De Caterina. "Basic mechanisms behind the effects of n-3 fatty acids on cardiovascular disease" Prostagl Leukot Essent Fat Acids, vol. 79, no. 3-5.pp. 109-115. 2008. 